\title{
Epictia collaris (Hoogmoed, 1977) (Reptilia: Squamata: Leptotyphlopidae), new record for the herpetofauna of Amapá and Brazil, with additional localities in French Guiana and a distribution map \\ Epictia collaris (Hoogmoed, 1977) (Reptilia: Squamata: Leptotyphlopidae), novo registro para a herpetofauna do Amapá e do Brasil, incluindo localidades adicionais na Guiana Francesa e um mapa de distribuição
}

\author{
Marinus S. Hoogmoed", Jucivaldo Dias Lima" \\ 'Museu Paraense Emílio Goeldi/MCTIC. Belém, Pará, Brasil \\ "Instituto de Pesquisas Científicas e Tecnológicas do Estado do Amapá. Macapá, Amapá, Brasil
}

\begin{abstract}
Epictia collaris is reported for the first time from Amapá and Brazil. We provide a map with all known localities of this species in Suriname, French Guiana, and Brazil. Some new data on habitat and colour in life are presented.

Keywords: Snakes. New distribution records. Guiana. Colouration.

Resumo: Registramos o primeiro exemplar de Epictia collaris para o estado do Amapá e para o Brasil, fornecendo um mapa com todas as localidades conhecidas desta espécie para o Suriname, a Guiana Francesa e o Brasil. Apresentamos alguns novos dados sobre habitat e cor do animal em vida.
\end{abstract}

Palavras-chave: Serpentes. Novos dados sobre distribuição. Guiana. Coloração.

HOOGMOED, M. S. \& J. D. LIMA, 2018. Epictia collaris (Hoogmoed, 1977) (Squamata: Leptotyphlopidae), a species of snake new for the herpetofauna of Amapá and Brazil, with additional localities in French Guiana and a distribution map. Boletim do Museu Paraense Emílio Goeldi. Ciências Naturais 13(3): 461-465.

Autor para correspondência: Marinus S. Hoogmoed. Museu Paraense Emílio Goeldi/MCTIC. Coordenação de Zoologia. Av. Perimetral, 1901 - Terra Firme. Belém, PA, Brasil. CEP 66077-530 (marinus@museu-goeldi.br).

Recebido em 06/08/2018

Aprovado em 19/09/2018

Responsabilidade editorial: Fernando da Silva Carvalho Filho

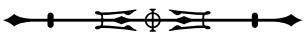




\section{INTRODUCTION}

Epictia collaris (Hoogmoed, 1977) was described as Leptotyphlops collaris on the basis of seven specimens from Suriname (Base Camp Nassau Mountains and Brownsberg) and two specimens from French Guiana (Montagne Mahury, and between Cayenne and Dégrad des Cannes) (Hoogmoed, 1977). Adalsteinsson et al. (2009) reviewed the Family Leptotyphlopidae and devided the genus Leptotyphlops in several genera. L. collaris was allocated to the resurrected genus Epictia Gray, 1845. The species was only known from Suriname and French Guiana, until it was collected in northern Amapá in 2005. We here report on new localities in French Guiana and Brazil.

\section{MATERIAL AND METHODS}

Data used are based on one recently collected specimen (IEPA 783), on literature, on pictures and on internet sites. Collection acronyms used follow Sabaj Pérez (2016).

\section{RESULTS}

\section{DISTRIBUTION}

After its description E. collaris was mentioned in several publications, all of which repeated the data provided in the original description or only mentioned the name (Abuys, 1982, 2003; Hoogmoed, 1983 [1982]; McDiarmid et al., 1999; Claessen, 2002; Avila-Pires, 2005; Wallach et al., 2014; Wallach, 2016). Gasc \& Rodrigues (1980) provided a new locality in French Guiana (Saut Pararé on the Arataye river, 4 10' 15.30" N 52 40' 57.58” W). Several authors (Chippeaux, 1987; Starace, 1998; Abuys, 2003; Ouboter \& Hoogmoed, 2017) combined the data for French Guiana from Hoogmoed (1977) and Gasc \& Rodrigues (1980). Abuys (2003) mentioned new material photographed on the Brownsberg (= Brown's Mountain), plateau (type locality) in June 1984, and on August 3, 2016, M.H. Edelman photographed another live specimen (Figure 1) on the top plateau (450 m) of the Brownsberg, Suriname, where it was found under a fallen tree trunk in closed rainforest. In French Guiana several authors provided new localities (arranged chronologically below) (Figure 2):

- Camp Muséum National d'Histoire Naturelle (MNHN) St. Eugène, Petit Saut, $4^{\circ} 51^{\prime} \mathrm{N} 53^{\circ} 00^{\prime} \mathrm{W}$ (personal communication of de Massary in 1998 to Starace, 2013);

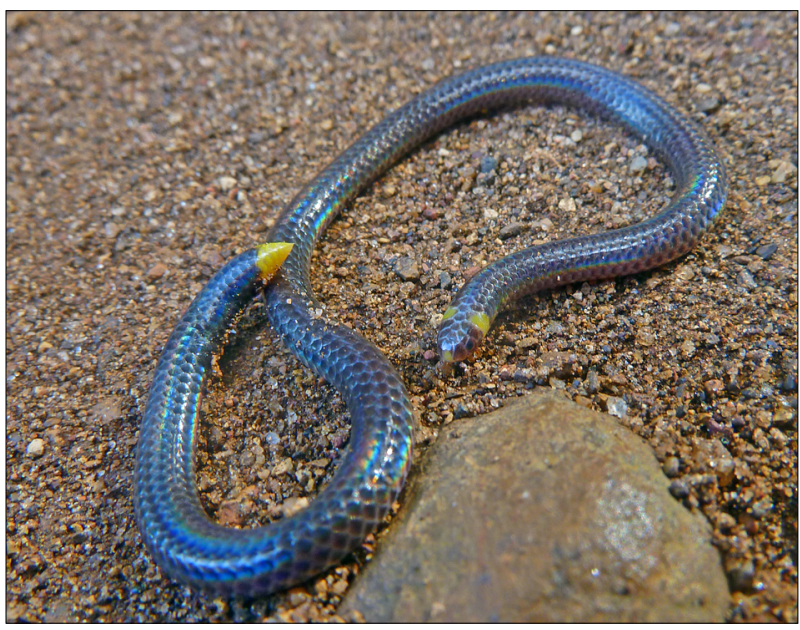

Figure 1. Epictia collaris, dorsolateral view of specimen photographed on Brownsberg, showing the distinctive yellow spots in the nuchal area, tip of snout and tip of tail. Photo: M. H. Edelman (2016).

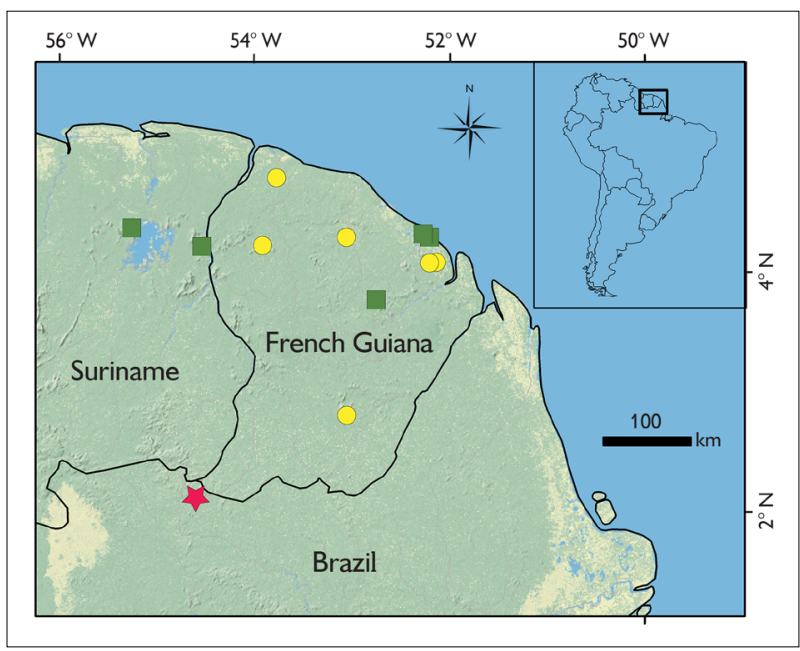

Figure 2. Distribution of Epictia collaris. Green squares: localities from literature; yellow dots: new localities in French Guiana; red star: new locality in Brazil. The two northeastern most localities in French Guiana represent Parque National Régionale Trésore (left) and Camp Patawa (right). The locality Montagne de Kaw is between those localities and for clarity has not been indicated with yet another dot. Map: T. C. S. Avila-Pires (2018).

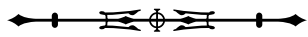


- Reserve biologique dirigée Lucifer Dékou-Dékou, $550 \mathrm{~m}, 4^{\circ} 47^{\prime} 15^{\prime \prime} \mathrm{N} 53^{\circ}$ 55' 10" W (Blanc \& Dewynter, 2005);

- Montagne de Kaw, 322 m, 4 33' 0.40” N 52 12' 21.60" W (Blanc \& Dewynter, 2005);

- Parque National Régionale Trésore, 200 m, 4 35' 28" N 52 18' 04" W (pictures on internet: Groot, 2006 and Spzigel, 2014);

- Camp Patawa, piste de Kaw, 177 m, 4 32' 40.74" N $52^{\circ} 9$ ' 9.29" W (personal communication of Bittencourt, Gower \& Wilkinson reported by Starace, 2013);

- Saut Sabbat, 523' 20.12" N 5340' 19.91” W (Starace, 2013);

- Mont Itoupé, 830 m, 301' 39" N 530 04' 39” W (picture on internet: Brusini, s. d.).

M. Dewynter (personal communication, April $24,2018)$ provided us with an unpublished map of the distribution of E. collaris in French Guiana, collated during the Red List preparation of French Guiana reptiles. The map is based on 24 specimens that occurred in 13 grid cells, a few of the localities (not published) used during that process are not in our list and map, but they all fall within the area (polygon) of occurrence shown in our map. The species was evaluated as Least Concern (UICN Comité Français \& MNHN, 2017) and the assumption was that it would occur in the entire forested area of French Guiana.

The presence of E. collaris in the Brazilian part of the Guiana Shield was to be expected, but extensive fieldwork in northern Pará did not register the species for the area (Avila-Pires et al., 2010).

On January 15, 2005, at 9:27 a.m. the junior author (JDL) collected a specimen of Epictia collaris in undisturbed terra firme forest, with little undergrowth and a leaf litter layer of $10-30 \mathrm{~cm}$ on the forest floor, near the tripartite border of Brazil, Suriname and French Guiana. The locality is in the extreme northwest of the municipality of Laranjal do Jari, on the Rio Mapaoni in the Parque Nacional Montanhas do Tumucumaque (2॰11' $36^{\prime \prime}$

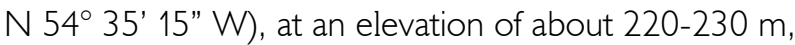
in the Brazilian state of Amapá (Bernard, 2008, p. 28), just south of the border with French Guiana (Figure 2). The specimen was collected while searching leaf litter deposited on a fallen tree trunk. This specimen extends the known distribution of $E$. collaris considerably to the south of formerly known localities, viz. $233 \mathrm{~km}$ SW of Saut Pararé in French Guiana and 285 km due South of Nassau Mountains in Suriname. This is the first record for Amapá and Brazil of this snake of which the known distribution until recently was thought to be limited to northeastern Suriname and northern French Guiana (Starace, 1998, 2013; Ouboter \& Hoogmoed, 2017). Lima (2008) did not mention this species, he only mentioned Leptotyphlops tenella Klauber, 1939, from the Rio Mapaoni locality, which was a wrong identification of the specimen here reported.

\section{DESCRIPTION}

The specimen is deposited in the collection of Instituto de Pesquisas Científicas e Tecnológicas do Estado do Amapá (IEPA) (registration number 783, field number TQ314). Its total length is $111 \mathrm{~mm}, \mathrm{SVL} 102 \mathrm{~mm}$, tail length $9 \mathrm{~mm}$, with a downward directed sharp spine at its tip. Its scalation characters of the head agree with those described and illustrated by Hoogmoed (1977). Total number of dorsal's between rostral and tip of tail 163, ventral's between mental and anal shield 151 (the first five distinctly smaller than the rest), subcaudals $15+1$, scales around midbody 14, scales around middle of tail 10. Tongue white, deeply bifurcated with long, narrow, conical tips. Colour in life of this specimen (fieldnotes JDL): brilliant, brown with several dark, longitudinal lines, head darker tending to black. In preservative brown with cream (in life yellow) spots on the rostral and mental (both small), a pair of larger cream spots on the lateral, posterior part of the head/neck region, a large cream spot on the tip of the tail (mostly on ventral part, dorsally just visible) and a large cream spot under the tail, immediately posterior of the cloacal opening. There are no distinct darker lines visible, but anteriorly four, more posteriorly

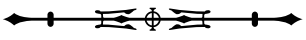


six, rows of dorsal scales show a darker brown area on the base of each scale. The head is only very slightly darker than the body.

Starace (2013) studied a specimen with a total length of $120 \mathrm{~mm}$. This makes it the largest specimen known. The size range of all other specimens known is $57-111 \mathrm{~mm}$.

Blanc \& Dewynter (2005), Groot (2006), Starace (2013), Spzigel (2014), INPN (2017) and Brusini (s. d.), provided good pictures of live specimens. From these pictures it is clear that the light spots are bright yellow in life (also see Figure 1). It should be noted that the picture in Groot (2006) is practically the same as one of the pictures in Blanc \& Dewynter (2005); apparently, this concerns the same specimen, only the angle under which the picture was taken differs slightly. Unfortunately INPN (2017) did not provide details about the location of the specimen pictured.

\section{ECOLOGICAL OBSERVATIONS}

Gasc \& Rodrigues (1980) reported two specimens (male and female) found $50 \mathrm{~cm}$ above the forest floor in an accumulation of fallen leaves at the base of the junction of leaves of a spiny palm (Astrocaryum) that function as a receptacle (funnel) to gather dead leaves. Blanc \& Dewynter (2005) mentioned that two specimens were collected at Montagne de Kaw in pitfalls. Groot (2006) also mentioned that the species was collected during an inventory of small mammals in Parque National Régionale Trésore. M. H. Hegelman (personal communication, 2018) found a specimen (Figure 1) on Brownsberg under a fallen tree trunk in closed rainforest at an altitude of $450 \mathrm{~m}$ in 2016.

\section{CONSERVATION}

IUCN (2016), UICN Comité Français \& MNHN (2017) and Ouboter \& Hoogmoed (2017) list this species as Least Concern, using IUCN criteria. The new distribution data presented here only fortify this conclusion. The specimen is known from undisturbed primary forest and from the surroundings of Cayenne, indicating it can support a certain level of disturbance. It probably occurs throughout French Guiana, eastern Suriname and in Brazil in Amapá and northern Pará.

\section{ACKNOWLEDGEMENTS}

The collecting license for the fieldwork in the Tumucumaque area was provided by Instituto Brasileiro do Meio Ambiente e dos Recursos Naturais Renováveis (IBAMA) (n. 3/2005). Fieldwork benefited greatly from the invaluable help of the $34^{\text {th }}$ Battalion of Infantry of the Brazilian Army in Macapá. Conservation International do Brasil (CI-Brasil) financed the expeditions in the Tumucumaque area. Maël Dewynter (French Guiana) provided important information. M. H. Edelman (Netherlands) and J. F. Spzigel (French Guiana) provided pictures of living specimens and shared locality data. Teresa Avila-Pires made the distribution map. We want to thank Museu Paraense Emílio Goeldi (MPEG) and IEPA for providing working space to, respectively, M. S. Hoogmoed and J. D. Lima.

\section{REFERENCES}

ABUYS, A., 1982. De slangen van Suriname, Deel I: de wormslangen. Litteratura Serpentium 2(2): 64-82.

ABUYS, A., 2003. De slangen van Suriname em de andere Guyana's: 1-592. Gopher Publishers, Groningen.

ADALSTEINSSON, S. A., W. BRANCH, S. TRAPE, L. J. VITT \& S. B. HEDGES, 2009. Molecular phylogeny, classification, and biogeography of snakes of the Family Leptotyphlopidae (Reptilia, Squamata). Zootaxa 2244: 1-50.

AVILA-PIRES, T. C. S., 2005. Reptiles. Bulletin of the Biological Society of Washington 13: 25-40. DOI: <https://doi. org/10.2988/0097-0298(2005)13[25:R]2.0.CO;2>.

AVILA-PIRES, T. C. S., M. S. HOOGMOED \&W. A. ROCHA, 2010. Notes on the vertebrates of northern Pará, Brazil: a forgotten part of the Guianan Region. I. Herpetofauna. Boletim do Museu Paraense Emílio Goeldi. Ciências Naturais 5(1): 13-112.

BERNARD, E. (Ed.), 2008. Inventários biológicos rápidos no Parque Nacional Montanhas do Tumucumaque, Amapá, Brasil. RAP Bulletin of Biological assessment 48: 1-145.

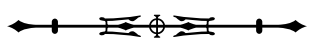


BLANC, M. \& M. DEWYNTER, 2005. Inventaire herpétologique du plateau de Lucifer, Réserve Biologique Dirigée de Lucifer DékouDékou. Rapport de Mission de Office National des Forêts 1-23. Available at: <https://montagnedor.debatpublic.fr/images/Autresdocs-etudes/Montagnedor-rapport-Onf-herpetofaune.pdf $>$. Accessed on: April 20, 2018.

BRUSINI, A., [s. d.]. France, Guyana, French Guyana Amazonian Park, heart area, Mount Itoupe, rainy season, burrowing snake on a mossy trunk (Epictia collaris). Hemis/Alamy Stock Photo. Available at: <https://www.alamy.com/stock-photo-france-guyana-frenchguyana-amazonian-park-heart-area-mount-itoupe-136057253. html>. Accessed on: April 20, 2018.

CHIPPEAUX, J.-P., 1987. Les Serpents de la Guyane Française. Faune Tropicale 28: 1-165.

CLAESSEN, H., 2002. De Slangen van de Guyana's. Deel II. Lacerta 60(2): 55-62.

GASC, J.-P. \& M. T. RODRIGUES, 1980. Liste préliminaire des Serpents de la Guyane Française. Bulletin du Musée National de Histoire Naturelle, 4ème Série 2A(2): 559-598.

GROOT, D., 2006. Berichten uit uw regenwoud. Trésor Nieuws 18. Available at: <http://www.tresorrainforest.org/frame_nl/tn018. html>. Accessed on: April 20, 2018.

HOOGMOED, M. S., 1977. On a new species of Leptotyphlops from Surinam, with notes on other Surinam species of the genus (Leptotyphlopidae, Serpentes). Notes on the herpetofauna of Surinam V. Zoologische Mededelingen 51(7): 99-123.

HOOGMOED, M. S., 1983 [1982]. Snakes of the Guianan region. Memorias do Instituto Butantan 46: 219-254.

INTERNATIONAL UNION FOR CONSERVATION OF NATURE AND NATURAL RESOURCES (IUCN), 2016. List of least concern reptiles. Available at: <https://ipfs.io/ipfs/ QmXoypizjW3WknFilnKLwHCnL72vedxjQkDDP1mXWo6uco/wiki/ List_of_least_concern_reptiles.html>. Accessed on: April 20, 2018.

INVENTAIRE NATIONAL DU PATRIMOINE NATURAL (INPN), 2017. Epictia collaris (Hoogmoed, 1977). Available at: <https:// inpn.mnhn.fr/espece/cd nom/721440?lg=en>. Accessed on: April 20, 2018.
LIMA, J. D., 2008. A herpetofauna do Parque Nacional do Montanhas do Tumucumaque, Amapá, Brasil, expedições I a V. In: E. BERNARD (Ed.): Inventários biológicos rápidos no Parque Nacional Montanhas do Tumucumaque, Amapá, Brasil. RAP Bulletin of Biological assessment 48: 38-50.

MCDIARMID, R. W., J. A. CAMPBELL \& T. A. TOURÉ, 1999. Snake species of the world: a taxonomic and geographic reference: $v .1$ : 11+511. The Herpetologists' League, Washington, D.C.

OUBOTER, P. \& M. S. HOOGMOED, 2017. Epictia collaris. The IUCN Red List of Threatened Species 2017: e.T178360A66749911. Available at: <https://www.iucnredlist.org/ species/178360/66749911>. Accessed on: April 20, 2018.

SABAJ PÉREZ, M. H., 2016. Standard symbolic codes for institutional resource collections in herpetology and ichthyology: an online reference. Version 6.5 (16 August 2016). American Society of Ichthyologists and Herpetologists, Washington. Available at: $<$ https://asih.org/sites/default/files/documents/symbolic_codes_for collections v6.5 2016.pdf>. Accessed on: April 20, $20 \overline{018 .}$

SPZIGEL, J. F., 2014. Epictia collaris. Available at: < http://www. reserve-tresor.fr/nl/phototheque/reptiles/>. Accessed on: April 20,2018

STARACE, F., 1998. Guide des serpentes et amphisbénes de Guyane: 1-449. Ibis Rouge Editions, Guadeloupe, Guyane Française.

STARACE, F., 2013. Serpents et amphisbénes de Guyane Française: 1-604. Ibis Rouge Editions, Matoury, Guyane.

UICN COMITÉ FRANÇAIS \& MNHN, 2017. La lista rouge des espèces ménacées en France. Faune vertebrée de Guyane: 1-34. UICN Comité Français/Muséum National d'Historie Naturelle, Paris.

WALLACH, V., 2016. Morphological review and taxonomic status of the Epictia phenops species group of Mesoamerica, with description of six new species and discussion of South American Epictia albifrons, E. goudotii, and E. tenella (Serpentes: Leptotyphlopidae: Epictinae). Mesoamerican Herpetology 3(2): 216-374.

WALLACH, V., K. L. WILLIAMS \& J. BOUNDY, 2014. Snakes of the World. A catalogue of living and extinct species: i-xvii, 1-1227. CRC Press, Boca Raton, Florida.

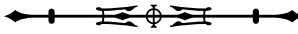


